\section{The case for reprecipitation of human bone as an event in a Bronze Age cist burial, Scotland}

\author{
Allan J. Hall, ${ }^{1}$ Lyn Wilson, ${ }^{2}$ \\ Maureen E. Young ${ }^{2}$ \\ 'Department of Archaeology, University \\ of Glasgow; '2Conservation Group, \\ Historic Scotland, Edinburgh, UK
}

\section{Abstract}

A hard whitish precipitate was observed on the lower part of the sandstone sidewalls and as pebble coatings in a Bronze Age cist burial near Forteviot, Strathearn, Scotland. The cist was discovered on excavation of a Neolithic henge in August 2009 during the joint Glasgow and Aberdeen Universities [Strathearn and Environs Royal Forteviot (SERF)] archaeological landscape research project and summer field school. Similar cists have not been found in this area. Scrapings of the precipitate proved on examination by powder X-ray diffraction to be hydroxyapatite. The mamillary material proved on examination by scanning electron microscopy to be calcium carbonate, calcite which had grown as groups of mm-size spheroids consisting of bundles of acicular crystals. Both components of the precipitate were also identified using oil immersion microscopy. Much organic material was preserved in the cist but neither (inorganic) bone nor teeth has been located to date (November 2010). The phosphatic mineral-precipitates provided the first confirmation that there had been bone and therefore an inhumation. Computational aqueous geochemistry using Geochemist's Workbench confirms that the inorganic calcium phosphate component of human bone is soluble in acidic fluid and demonstrates how it can reprecipitate with change in fluid chemistry. Bone dissolution should be anticipated as being an expected early process when a human body produces an acidic fluid rich in organic molecules as it decays in an essentially closed, but wet, anoxic environment. Any precipitates on grave stonework should be identified as such material could represent human remains and could also provide evidence of environmental processes in the archaeological setting of a burial.

\section{Introduction}

After the organic contents and metal objects were removed and access was permitted, a hard white precipitate was observed on the lower part of the sandstone sidewalls in a recently discovered Bronze Age cist dagger burial near Forteviot, Strathearn, Scotland (Driscoll et al., 2010). This was sampled rapidly by taking a few scrapings that are the subject of this paper. The cist was discovered on excavation of a Neolithic henge feature in August 2009 during the joint Glasgow and Aberdeen Universities [Strathearn and Environs Royal Forteviot (SERF)] archaeological landscape research and summer field school project (Driscoll et al., 2010); the excavation was of a cropmark in a wheat field situated over welldrained glacial pebbly alluvial deposits. Similar cists have not been found in this area. There was no bone preserved in the cist but abundant organic matter and adipocere-like soft whitish, creamy pellets. Post-ex investigation of the diverse finds is on-going. There were also whitish pebbles on the tomb floor (Driscoll $e t$ al., 2010), some light-coloured due to a coating of chemical precipitate. The preservation of organic matter such as plant material, yet not skeletal bone, was surprising. To date (November 2010), no organic matter indicative of the former presence of a corpse has been identified; apodicere-like material (cream-coloured and of a soft consistency) collected by archaeologists shortly after opening the cist proved to be aggregates of fine gypsum crystals.

\section{Materials and Methods}

Powder X-ray diffraction (XRD) was used to identify the white precipitate; the samples were ground to a fine powder in a mortar and pestle and applied to a glass slide in an acetone slurry. XRD analysis was carried out using a Thermo Electron ARL X'TRA XRD at $45 \mathrm{~mA}$ $44 \mathrm{kV}$, step scanning at $0.2^{\circ}$ from 5 to $70^{\circ} 2$ theta.

Scanning electron microscopy (SEM) with energy dispersive X-ray analysis (EDX) was undertaken using a Zeiss Sigma field-emission environmental SEM hosted by Geographic and Earth Sciences, University of Glasgow. A fragment of the botryoidal white precipitate was simply mounted on carbon on an aluminium stub, carbon coated and examined.

Transmitted polarised-light oil-immersion optical microscopy was undertaken by simply spreading some grains of precipitate in oil of refractive index, 1.644 on a glass slide with cover slip. A Swift MP120 microscope (Swift Optical Instruments Inc., Schertz, TX, USA) was used and fitted with a consumer singlelens reflex (SLR) digital camera, Canon 450D (Canon, Tokyo, Japan) for the photomicrographs.
Correspondence: Allan J. Hall, Department of Archaeology, University of Glasgow, University Ave, G12 800 Glasgow, UK.

Tel. +44.0141.330.3722 - Fax: +44.0141.330.3544.

E-mail: allan.hall@glasgow.ac.uk

Key words: cist, bone dissolution, Bronze Age, geochemistry.

Acknowledgements: we are indebted to SERF directors Drs. Kenny Brophy (Glasgow Archaeology) and Gordon Noble (Aberdeen Archaeology) for providing access to the cist. SERF director Professor Stephen Driscoll (Glasgow Archaeology) is thanked for supporting the project and Peter Chung, (Geographic and Earth Sciences, Glasgow) is thanked for providing SEM support. An anonymous referee is thanked for constructive criticism of the first draft of the paper.

Citation: Hall AJ, Wilson L, Young ME, 2014. The case for reprecipitation of human bone as an event in a Bronze Age cist burial, Scotland. In: RH Tykot (ed.), Proceedings of the $38^{\text {th }}$ International Symposium on Archaeometry - May $10^{\text {th }}-14^{\text {th }}$ 2010, Tampa, Florida. Open Journal of Archaeometry 2:5255.

Presented at the $38^{\text {th }}$ International Symposium on Archaeometry - May $10^{\text {th }}-14^{\text {th }} 2010$, Tampa, Florida.

This work is licensed under a Creative Commons Attribution 3.0 License (by-nc 3.0).

CC Copyright A.J. Hall et al., 2014

Licensee PAGEPress, Italy

Open Journal of Archaeometry 2014; 2:5255 doi:10.4081/arc.2014.5255

Computational geochemistry was undertaken using the Geochemist's Workbench (Bethke, 1996; http://www.gwb.com), version 4.0.

\section{Results and Discussion}

The precipitate consisting of hard white mammillary material and associated powder was scraped from the cist wall (Figures 1 and 2) once the scant remains on the floor of the cist had been carefully removed for conservation. The white powder proved on examination by powder XRD to be calcium phosphate hydroxide, hydroxyapatite (Figure 3). The spectrum, not surprisingly indicates that the precipitate is well-crystallised and matched archaeological bone (Figure 3); the XRD pattern matches that of heated (Shipman et al., 1984) or diagenetic (Hedges et al., 1995) bone rather than fresh bone. The mamillary material, visually similar to the lead-coffin-wall precipitate reported by Charlier et al. (2008), 
proved on examination using a SEM fitted with an EDX to contain major $\mathrm{Ca}, \mathrm{C}$ and $\mathrm{O}$ and hence could be calcium carbonate, presumably calcite which had grown as groups of mmsized spheroids consisting of bundles of $c .100$ acicular crystals $c$. 30 microns long (Figure 4). Surprisingly, no calcite was detected with the hydroxyapatite of the XRD trace (Figure 3). Both components of the precipitate were also observed and identified using oil immersion microscopy (Figure 5a and 5b). Using planepolarised light (Figure 5a and 5b), the distinctive texture of the mamillary and birefringent calcite contrasts with the granular texture of the low relief hydroxyapatite. Using crossedpolars, the phosphate precipitate is similar to bone and has low order interference colours in contrast to those of the birefringent calcite.

There was much organic material preserved in the cist but no inorganic bone has been located to date (October 2010). The phosphatic material of the white precipitate therefore provided the first evidence that there had been bone and therefore most probably an inhumation in the cist. The only additional chemical evidence of an inhumation determined to date (October 2010) is the localised enhanced phosphate content of the sediment in the base of the cist. White pebbles lay on the cist floor; such white pebbles, typically forms of quartz, are often found in prehistoric burial sites. Scrapings of powder from a pebble which had been left exposed to the weather for a few weeks proved by XRD to be the complex phosphate, taranakite, $\mathrm{K}_{3} \mathrm{Al}_{5}\left(\mathrm{HPO}_{4}\right)_{6}\left(\mathrm{PO}_{4}\right)_{2} \cdot 18 \mathrm{H}_{2} \mathrm{O}$ (Weiner et al., 2002). This material is not discussed in detail here because it may have formed by post-excavation change on weathering, although the phosphorus content still points to the former presence of bone in the cist. The chemical/mineralogical composition of white precipitates on any pebbles as well as on grave stonework should be identified routinely as such material could represent human remains and could also provide evidence of environmental processes in the archaeological setting of a burial.

Computational aqueous geochemistry using

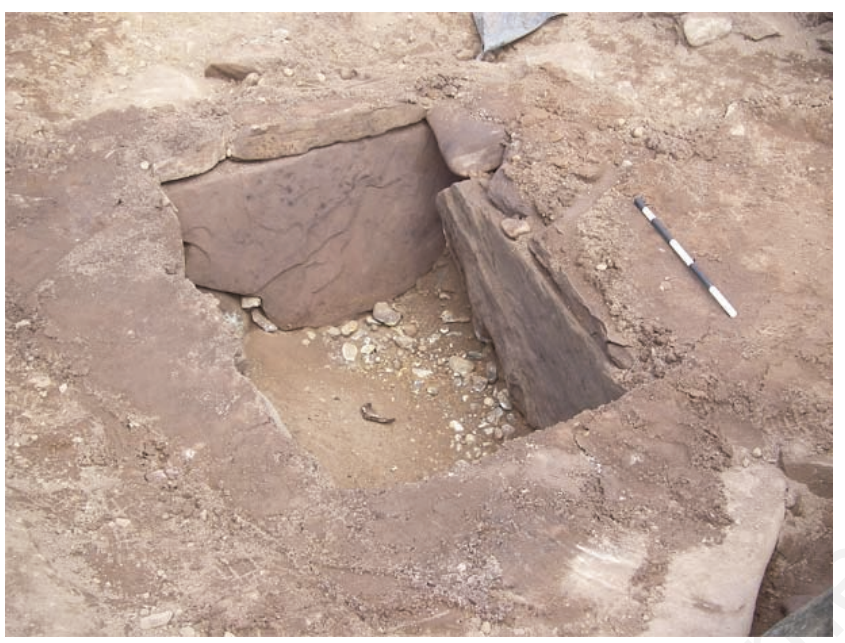

Figure 1. The cist shortly after opening. Looking towards the South East into the uncovered cist. Note the fragment of a wooden bowl on the floor of the cist on a slight mound of sandy material.

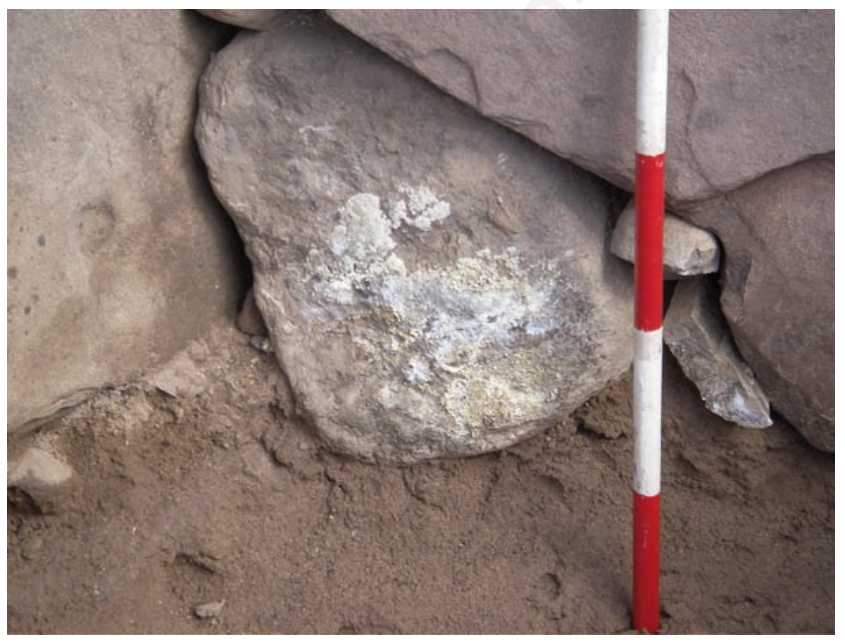

Figure 2. Precipitate on stone of wall [top left (South East) corner]. The colour variation from cream to pale bluish-green is more evident in the photo than in the field. The bluish-green colour on this and other precipitates is now suspected to be due to copper from the dagger blade.

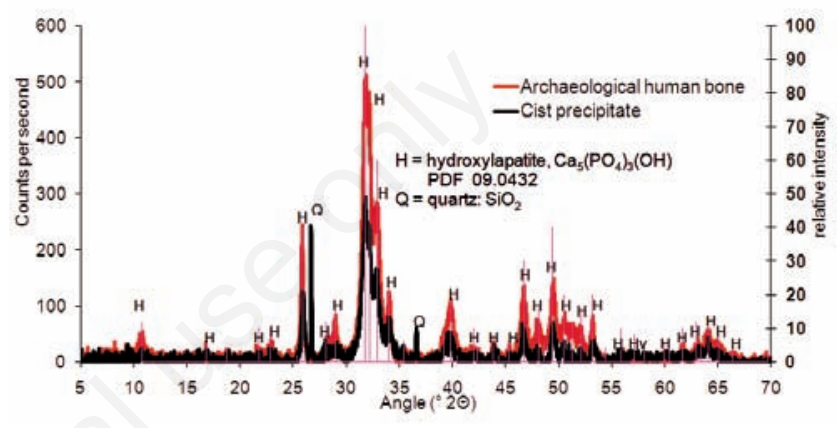

Figure 3. X-ray diffraction trace of hydroxyapatite showing close match with Bronze Age archaeological human bone and mineral hydroxyapatite (synonym, hydroxylapatite). The labelled peak positions are those of PDF 09-0432, hydroxylapatite.

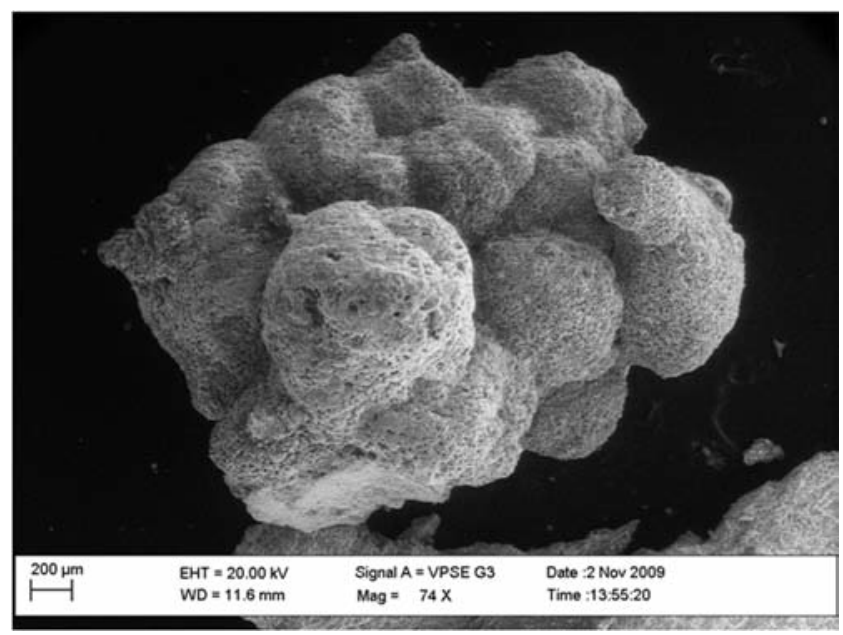

Figure 4. Low magnification scanning electron microscopy image of mamillary precipitate of calcite. 

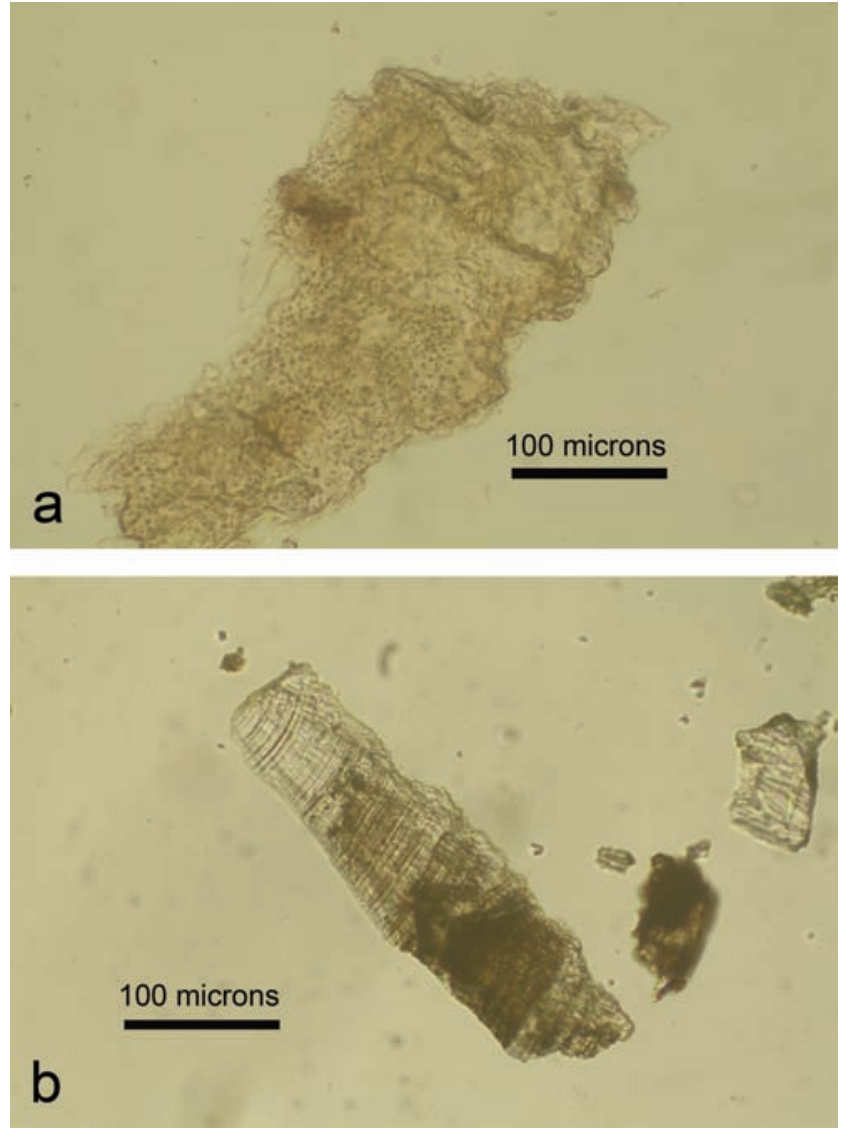

Figure 5. a) Scrapings of the phosphatic precipitate mounted in oil and viewed using plane-polarised light microscopy; b) a calcite crystal from the mamillary precipitate mounted in oil and viewed using plane-polarised light microscopy. Note the growth bands perpendicular to the elongated crystal (both images taken in picture processing language).

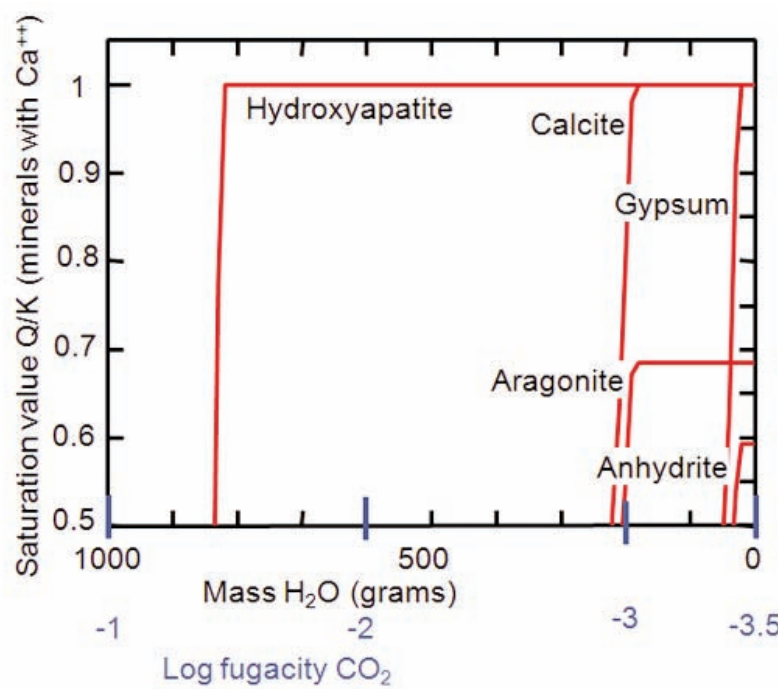

Figure 6. Graphical output of React Program of Geochemist's Workbench showing saturation index of minerals containing $\mathrm{Ca}^{++}$computed for falling water activity and $\mathrm{CO}_{2}$ fugacity. Model demonstration of reprecipitation of bone (hydroxyapatite and calcite) dissolved in carbonic acid (representing low $\mathrm{pH}$ cist fluid). The $\mathrm{x}$-axis has been labelled to show the parallel decrease in $\mathrm{CO}_{2}$ as water is evaporated in the model. As the fluid is evaporated and $\mathrm{CO}_{2}$ degassed, hydroxyapatite, calcite and gypsum become increasingly concentrated and precipitate. One $\mathrm{kg}$ of water is used to dissolve bone (as $100 \mathrm{mg}$ of hydroxyapatite +10 $\mathrm{mg}$ calcite) and a nominal $10 \mathrm{mg}$ gypsum. Of water, $999 \mathrm{~g}$ is evaporated in the model. The starting log fugacity of $\mathrm{CO}_{2}$ is a nominal high value, -1 , and is decreased to the standard atmospheric value, -3.5 , to simulate $\mathrm{CO}_{2}$ loss; this is the main reason for calcite precipitation.
Geochemist's Workbench (http://www.gwb. com) leads to the prediction that the inorganic calcium phosphate component of human bone will dissolve in an acidic fluid and can reprecipitate with change in fluid chemistry. The dissolution of bone [hydroxyapatite, $\mathrm{Ca}_{5}\left(\mathrm{PO}_{4}\right)_{3} \mathrm{OH}$ ] in a low $\mathrm{pH}$ (acidic) solution (Nielsen-Marsh et al., 2000) can be demonstrated using a calculated activity diagram (Geochemist's Workbench Act2; Bethke, 1996). The React Program of Geochemist's Workbench (Bethke, 1996) provides a model demonstration (Figure 6) of how reprecipitation of hydroxyapatite (bone) dissolved in carbonic acid (representing low $\mathrm{pH}$ cist fluid) can take place. As fluid evaporates and $\mathrm{CO}_{2}$ degasses, hydroxyapatite, calcite and gypsum become increasingly concentrated and precipitate.

\section{Conclusions}

The bone has dissolved, but organic materi- al has been preserved, therefore the environment was anoxic and acidic. Bone, presumably human, has dissolved in a pool of acidic body fluid and been reprecipitated at the base of the cist on the cist walls and on pebbles on the cist floor. The acidic nature of decomposition fluid is as reported by Charlier et al. (2008) but in contrast, an alkaline decomposition fluid is expected from the research using pig proxies by Adlam and Simmons (2007) and Pringle $e t$ al. (2010). This process was an event when there was a limited amount of fluid in the cist, presumably a fluid mixture mainly from the decayed body and some from local groundwater which could well have seeped into the cist from the sides or risen from below. The environment was anoxic and acidic hence bone dissolved but some organic matter survived. While there may have been water present at times in the floor of the cist, the survival of the precipitate and the organic matter mean that groundwater could not have been passing through the cist in abundance.

Finally, all this considered, we can put out some implications. Bone dissolution should be anticipated as being an expected early process when a human body decays in an essentially closed but wet, anoxic environment and presumably produces an acidic fluid rich in organic molecules. Traces of organic material including organic molecules of human origin are anticipated to be present in the cist contents, possibly within fluid inclusions in the secondary crystalline products such as the phosphate and carbonate precipitates and the metal corrosion products. Archaeological bone preservation is anticipated to be due to exceptional environmental conditions.

\section{References}

Adlam RE, Simmons T, 2007. The effect of repeated physical disturbance on soft tissue decomposition: are taphonomic studies an accurate reflection of decomposition? J Forensic Sci 52:1007-13.

Bethke CM, 1996. Geochemical reaction modelling: concepts and applications. 0xford 
University Press, 0xford.

Charlier PG, Bouchet F, Huynh-Charlier I, Carlier R, Mazel V, Richardin P, Brun L, Blondiaux J, Lorin de la Grandmaison G, 2008. The microscopic (optical and SEM) examination of putrefaction fluid deposits (PFD). Potential interest in forensic anthropology. Virchows Arch 453:377-86.

Driscoll S, Brophy K, Noble G, 2010. The Strathearn Environs and Royal Forteviot project (SERF). Available from: http://www.antiquity.ac.uk/projgal//driscoll 323/
Hedges REM, Millard AR, Pike AWG, 1995. Measurements and relationships of diagenetic alteration of bone from three archaeological sites. J Archaeol Sci 22:201-9.

Nielsen-Marsh C, Gernaey A, Turner-Walker G, Hedges R, Pike A, Collins M, 2000. The chemical degradation of bone. In: M. Cox, S. Mays (eds.) Human osteology in archaeology and forensic science. Cambridge University Press, Cambridge, pp 439-54.

Pringle JK, Cassella JP, Jervis JR, 2010. Preliminary soilwater conductivity analysis to date clandestine burials of homocide victims. Forensic Sci Int 198:126-33.

Shipman P, Foster GF, Shoeninger M, 1984. Burnt bones and teeth: and experimental study of colour, morphology, crystal structure and shrinkage. J Archaeol Sci 11:30725.

Weiner S, Goldberg P, Bar-Yosef 0, 2002. Three-dimensional distribution of minerals in sediments of Hayonim Cave, Israel: diagenetic proceses and archaeological implications. J Archaeol Sci 29:1289-308. 